\title{
An update in the structure, function, and regulation of V-ATPases: the role of the $\mathbf{C}$ subunit
}

\author{
Pérez-Sayáns, M. ${ }^{a *}$, Suárez-Peñaranda, JM. ${ }^{b}$, Barros-Angueira, $F^{c}$, \\ Diz, PG. ${ }^{d}$, Gándara-Rey, JM. ${ }^{e}$ and García-García, A. ${ }^{e}$ \\ ${ }^{a}$ Oral Medicine, Oral Surgery and Implantology Unit, Faculty of Medicine and Dentistry, \\ Entrerríos s/n, CP 15782, Santiago de Compostela, Spain

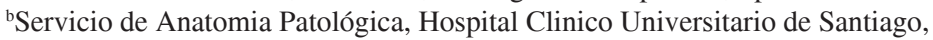 \\ Choupana s/n, CP 15706, Santiago de Compostela, Spain \\ 'Unidad de Medicina Molecular - Fundación Pública Galega de Medicina Xenómica. \\ Edificio de Consultas planta -2, Hospital Clinico Universitario, CP 15706, Santiago de Compostela, Spain \\ ${ }^{\mathrm{d} D e p a r t m e n t}$ of Clinical Epidemiology, Edificio de Consultas Planta 0, CP 15706, \\ Complejo Hospitalario Universitario de Santiago, Santiago de Compostela, Spain

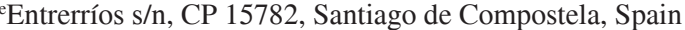 \\ *e-mail: perezsayans@gmail.com \\ Received January 4, 2011 - Accepted February 23, 2011 - Distributed February 29, 2012
}

(With 6 figures)

\begin{abstract}
Vacuolar ATPases (V-ATPases) are present in specialized proton secretory cells in which they pump protons across the membranes of various intracellular organelles and across the plasma membrane. The proton transport mechanism is electrogenic and establishes an acidic $\mathrm{pH}$ and a positive transmembrane potential in these intracellular and extracellular compartments. V-ATPases have been found to be practically identical in terms of the composition of their subunits in all eukaryotic cells. They have two distinct structures: a peripheral catalytic sector (V1) and a hydrophobic membrane sector (V0) responsible for driving protons. V-ATPase activity is regulated by three different mechanisms, which control pump density, association/dissociation of the V1 and V0 domains, and secretory activity. The $\mathrm{C}$ subunit is a 40-kDa protein located in the V1 domain of V-ATPase. The protein is encoded by the ATP6V1C gene and is located at position 22 of the long arm of chromosome 8 (8q22.3). The $\mathrm{C}$ subunit has very important functions in terms of controlling the regulation of the reversible dissociation of V-ATPases.
\end{abstract}

Keywords: V-ATPases, proton transport, ATP6V1C1,V1 domain, V0 domain, C subunit.

\section{Uma atualização na estrutura, função e regulação das V-ATPases: o papel das subunidades $\mathrm{C}$}

\section{Resumo}

As Vacuolar ATPases (V-ATPases) estão presentes nas células especializadas em secreção de protões, nas quais eles são bombeados através das membranas de vários organelos intracelulares e da membrana plasmática. $\mathrm{O}$ mecanismo de transporte de protões é eletrogênico e estabelece um $\mathrm{pH}$ ácido e um potencial transmembrana positivo nestes compartimentos intracelulares e extracelulares. As V-ATPases foram encontradas em todas as células eucarióticas, praticamente idênticas em termos de composição das suas subunidades. Elas têm duas estruturas distintas: um setor periférico catalítico (V1) e uma membrana hidrofóbica (V0), responsável pela condução de protões. A atividade das V-ATPases é regulada por três mecanismos diferentes, os quais controlam a densidade de bomba, associação/dissociação de domínios V1 e V0, e a atividade secretora. A subunidade C é uma proteína de 40-kDa, localizada no domínio V1 da V-ATPase. Essa proteína é codificada pelo gene ATP6V1C e está localizada na posição 22 do braço longo do cromossomo 8 (8q22.3). A subunidade $\mathrm{C}$ tem funções muito importantes em termos de controle do regulamento da dissociação reversível da V-ATPase.

Palavras-chave: V-ATPases, transporte de protões, ATP6V1C1, domínio V1, domínio V0, subunidade C. 


\section{Introduction}

ATPases are enzyme systems that originated in a common ancestor and are distributed universally among all organisms. There are three types of ATPases: those found in archaea (A-ATPases), synthases (F-APTases), and vacuole or vacuolar ATPases (V-ATPases) (Nelson and Nelson, 1989). They are essential for life and have in common the fact that they create an electrochemical ion gradient across the membrane to hydrolyse or synthesize ATP. Structurally, they are enzymatic complexes that work as molecular rotary motors. They have conserved their structure and function throughout evolution. ATPases are formed by two domains, a hydrophobic domain (A0, $\mathrm{V} 0$, and F0) and a hydrophilic domain (A1, V1, and F1) connected by a central axis and either one or two lateral axes. The polypeptides of greatest molecular weight, $\alpha$ and $\beta$ in F-ATPases, and B and A in V-ATPases and A-ATPases, respectively, were generated by gene duplication and conserve a very high degree of homology Domin (Domínguez and Tuena, 2005; Marshansky and Futai, 2008), albeit with important differences. The V-ATPase V0 domain, for example, which is equivalent to the F-APTase F0 domain, is not an open proton channel (Zhang et al., 1992). In this article, we are going to discuss V-ATPases.

\section{The Vacuolar or V-ATPase Proton Pump: Biological Functions}

Unlike F-ATPases, whose primary function in eukaryotic cells is to generate ATP from proton motive force, V-ATPases function exclusively as ATP-dependent proton pumps, performing diverse biological functions within cells (Nelson, 1992; Kane, 1999; Saroussi and Nelson 2008; Stevens and Forgac, 1997.

\subsection{Membrane transport}

V-ATPases play an important role in receptor-mediated endocytosis (Forgac, 1998), intracellular transport, and the acidification of late endosomes (Kane, 1999; Stevens and Forgac, 1997; Nishi and Forgac, 2002; KawasakiNishi et al., 2003; Finbow and Harrison, 1997). Vacuolar acidification has also been reported to be involved in the transport of lysosomal enzymes from the Golgi apparatus to the lysosomes (Stevens and Forgac, 1997; Moriyama and Nelson, 1989). V-ATPases appear to play an important role in the creation of the microenvironment needed for correct protein transport, exchange, and secretion (Schoonderwoert et al., 2000).

\subsection{Plasma membrane functions}

Although V-ATPases were initially identified in intracellular compartments, knowledge on the roles they play in the plasma membrane has increased enormously. V-ATPases located at the apical membrane of type A intercalated cells are involved in the secretion of protons into renal fluid (Smith et al., 2005; Van Hille et al., 1993). Type B intercalated cells, whose function is to secrete bicarbonate, also contain V-ATPases, but they are located between the apical and basolateral membranes (Nishi and Forgac, 2002; Van Hille et al., 1993). In macrophages and neutrophils, plasma membrane V-ATPases (pmVATPases) are involved in the homeostasis of cytoplasmic pH (Stevens and Forgac, 1997; Nishi and Forgac, 2002; Nanda et al., 1996). These ATPases also play an important role in bone reabsorption (Marshansky and Futai, 2008; Stevens and Forgac, 1997; Nishi and Forgac, 2002; Smith et al., 2005; Van Hille et al., 1993) and appear to be involved in the development of tumor metastasis. Many tumor cells secrete lysosomal enzymes that participate in the degradation of the extracellular matrix required for metastatic invasion. These enzymes have a low optimal $\mathrm{pH}$ and it is the V-ATPases that are responsible for acidifying the microenvironment (Nishi and Forgac, 2002; Stevens and Forgac, 1997; Martínez-Zaguilan et al., 1993). Another of their functions is to regulate sperm motility and maturation on the apical membrane of epididymal cells and vas deferens by stabilising the sperm medium) (Nishi and Forgac, 2002).

\subsection{Additional functions}

The low $\mathrm{pH}$ maintained by V-ATPases in lysosomes and phagosomes is necessary for the activity of the degradative enzymes in these compartments (Sun-Wada et al., 2003a, b, 2004; Kurashima et al., 1996). In several intracellular compartments, including lysosomes and secretory vesicles, the proton gradient and/or the membrane potential generated by V-ATPases, gives rise to the transport of small molecules and ions (Nishi and Forgac, 2002; Kurashima et al., 1996). The driving force necessary for the accumulation of neurotransmitters in synaptic vesicles is proton motive force, which is generated by V-ATPases (Nelson and Harvey, 1999). The fusion-fission balance of the vacuolar system of eukaryotic cells is also controlled by V-ATPases, i.e. via the interaction between vacuolar SNARE proteins and GTPase Vps1p (it is a reminiscent of vacuole structures seen in the deletion mutant of the yeast dynamin-like GTPase, which is defective in vacuole fission. Hence, vacuole fragmentation requires proton translocation by the V-ATPase) (Baars et al., 2007, Muller et al., 2003). In murine $\beta$-pancreatic cells, V-ATPases also perform insulin exocytosis functions (Marshansky and Futai, 2008). Exocytosis in eosinophils is also regulated by V-ATPases (Kurashima et al., 1996). It is possible that pmV-ATPases bind to the cytoskeleton considering that mutations in the gene encoding the V-ATPase E subunit cause changes in cell morphology and cytoskeletal actin. The association between V-ATPase subunits and other cellular proteins, for example, that which occurs between the $\mathrm{C}$ subunit of the V0 domain and the E5 oncoprotein, or between platelet-derived growth factor (PDGF) and b1 integrin, indicate that these subunits play a role in cell growth and transformation. V-ATPases also allow the entry of certain viruses (e.g. influenza) and toxins (e.g. diphtheria) into the intracellular space via the binding of these pathogens to the endosomal membrane (Stevens and Forgac, 1997). In the case of the human immunodeficiency virus (HIV), 
the association between the V-ATPase $\mathrm{H}$ subunit and the HIV-1 Nef protein, which controls the expression of CD4 (the main HIV receptor), facilitates endocytosis of Nef and/ or alterations in the acidification of the endosomal pathway by this protein (Nishi and Forgac, 2002; Marshansky and Futai, 2008). The most recent function attributed to $\mathrm{V}$-ATPases is their involvement in the regulation of cell-cell fusion to form larger cells, as is the case with osteoclasts and macrophages) (Wada et al., 2008).

\section{V-ATPases AS ATP-Dependent Proton Pumps}

ATP is a labile chemical compound present in all cells. It is a combination of adenosine, ribose, and three phosphate radicals. The last two phosphate radicals are attached to the rest of the molecule by high-energy bonds. When released, each of these two radicals release 12000 calories of energy. When ATP loses the first phosphate radical, it becomes adenosine diphosphate and when it loses the second one, it becomes adenosine monophosphate (AMP). ATP is present at all points of the cytoplasm and nucleoplasm of all cells, and practically all physiological mechanisms obtain the energy they need from ATP. At the same time, the gradual oxidation of foods in the cell releases energy, which is then used to form ATP, thus ensuring that ATP levels are maintained at all times; all this energy transfer occurs via coupled reactions (Wada et al., 2008, Martínez-Munoz and Kane, 2008; Breton and Brown, 2007; Forgac, 2007; Nelson et al., 2000, Wieczorek et al., 1999).

In summary, ATP is an intermediate compound that has the unique ability to participate in many coupled reactions, including reactions with food to extract energy and also with many physiological mechanisms to supply the energy required for their functioning. For this reason, ATP has been referred to as an energy currency, which can be generated and used again and again by organisms (Cipriano et al., 2008). The force generated by V-ATPases in organelles and eukaryotic cell membranes - known as proton motive force (Drory and Nelson, 2006) - is used as a driving force by numerous secondary transport processes (Nelson and Harvey, 1999; Nelson et al., 2000).

$\mathrm{V}$-ATPases are present in the plasma membrane of specialized proton secretory cells (Nelson and Harvey, 1999, Wieczorek et al., 1999) in which they pump protons across the membranes of diverse intracellular organelles (lysosomes, endosomes, secretory granules, etc.). This transport mechanism is electrogenic and establishes an acid $\mathrm{pH}$ gradient and a positive transmembrane potential within these intracellular compartments (Philippe et al., 2002; Harvey and Wieczorek, 1997). The mechanism is rotary and permits the hydrolysis of ATP in an almost identical fashion to that which occurs with $\mathrm{Na}+$-ATPase archaebacteria such as Enterococcus hirae or H+-ATPases in Thermus thermophilus (Forgac, 2007).

V-ATPase, which is usually located apically to the plasma membranes of epithelial cells, towards the cytoplasmic side of the membrane, pumps $\mathrm{H}+$ out of the cell. This pumping of protons always allows a trans-positive voltage, accompanied, however, by several events. The voltage thus can dissipate, meaning that the trans-compartment can become acidic, basic, or neutral, depending on the nature of the parallel channels or porters accompanying the proton (Harvey, 1992). V-ATPases can consequently supply energy to the membrane, regulate intracellular $\mathrm{pH}$, and cause extracellular acidification or alkalinization (Nelson and Harvey, 1999).

According to Martínez-Muñoz and Kane (2008), $\mathrm{V}$-ATPase activity is essential in the short term for both vacuolar acidification in response to the glucose metabolism and the efficient regulation of $\mathrm{pH}$ homeostasis. In the long term, V-ATPases appear to be involved in the stable localization of Pma1p at the plasma membrane (Martínez-Muñoz and Kane, 2008). Pma1p is a type $\mathrm{P}$ proton pump located in the plasma membrane and responsible for regulating $\mathrm{pH}$. Like V-ATPases, these pumps are electrogenic pumps that use ATP hydrolysis to extrude protons from the cytosol (Martínez-Muñoz and Kane, 2008).

It used to be widely accepted that $\mathrm{Na}+$ motive force, generated by $\mathrm{Na}+/ \mathrm{K}+$ ATPase, was the main energy provider for the plasma membrane in animal cells but it was recently discovered that V-ATPases play a more important role in this respect (Nelson and Harvey, 1999).

\section{V-ATPase Structure and Regulation: the c Subunit}

\subsection{V-ATPase structure}

The V-ATPase proton pump has multiple subunits, each with multiple isoforms, hence the need for a clear, standardised nomenclature system. Initially, the HUGO Gene Nomenclature Committee agreed to use the ATP as the stem, or root, symbol. ATP6, for example, indicated ATPase, $\mathrm{H}+$ transport, lysosomal (vacuolar proton pump). In 2003, the nomenclature system for genes encoding V-ATPase subunits was revised and it was decided to maintain the root ATP6 and add the domain to which a particular subunit belonged, followed by the letter of the subunit, and finally the number of the isoform, where relevant, (e.g. ATP6V1C1, ATP6V1E, etc.) (Smith et al., 2003).

V-ATPase structure, function, biogenesis, and regulation was widely revised by Stevens and Forgac (1997). We will use the nomenclature system proposed by these authors to explain the structural subunits of V-ATPase together with relevant modifications based on recent research using transmission electron microscopy) (Wilkens et al., 2005).

V-ATPases have been found to be practically identical in terms of the composition of their subunits in all eukaryotic cells. They have two distinct structures: a peripheral catalytic sector (V1) and a hydrophobic membrane sector (V0) responsible for driving protons) (Gruber, 2005). The catalytic sector is composed of five polypeptides known as subunits $\mathrm{A}, \mathrm{B}, \mathrm{C}, \mathrm{D}$, and $\mathrm{E}$, with a molecular weight, 
in decreasing order, ranging from 72 to $33 \mathrm{kDa}$. Recent advances in knowledge of the mechanism of action of F-ATPases have clarified the relationship between function and structure for each of the subunits of these enzymes (Qi et al., 2007, Inoue et al., 2005).

Each ATPasae subunit is believed to have between one and four parts of a mechanochemical complex (Nelson and Harvey, 1999) (Figure 1): 1) a catalytic unit, 2) a shaft, 3) a hook, and 4) a turbine. In the next section, we will analyze the structure and function of the different subunits (Nelson and Harvey, 1999).

\subsubsection{Catalytic subunits}

A subunit: molecular weight of $68 \mathrm{kDa}$. Its function is to bind ATP and catalyze its hydrolysis.

B subunit: molecular weight of $57 \mathrm{kDa}$. It works as a regulatory subunit containing the ATP binding site and might also contribute as an important remnant for the catalytic function of the A subunit.

The main function of the catalytic sector is to bind ATP and catalyze ATP hydrolysis, while the main function of the membrane sector is to drive protons across the membrane. The energy generated by these two processes is capable of catalyzing mechanochemically induced conformational changes (Nelson and Harvey, 1999). Indeed, Boyer (1993) proposed two decades ago that ATP hydrolysis catalyzed by F-ATPase \#a and \#b subunits induced the rotation of the shaft and the pumping of protons across the membrane. The hook, in turn, would prevent the catalytic unit from rotating.

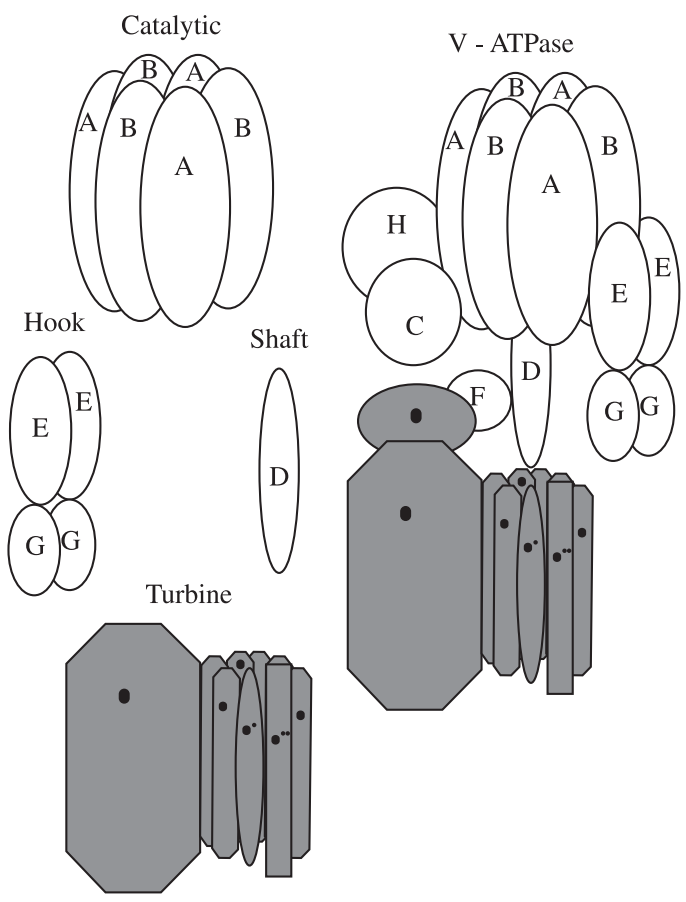

Figure 1. Structural V-ATPase subunits. Distribution of various subunits in four functional parts of the enzyme: catalytic unit, shaft, hook, and turbine (Stevens and Forgac, 1997).

\subsubsection{Shaft}

D subunit: molecular weight of $28 \mathrm{kDa}$. This subunit might play an important role in the union between ATP hydrolysis and proton pumping. It behaves like a rotary shaft, acquiring its rotational movement from conformational changes in the A subunit and providing torque to the turbine and protons in the membrane sector. Recent studies have confirmed that the D subunit is essential for embryonic development (Miura et al., 2003).

\subsubsection{Hook}

E subunit: molecular weight of $27 \mathrm{kDa}$. This subunit contains long alpha-helices, hence the suggestion that it might form part of the shaft. A newer theory, however, holds that the E subunit functions as a hook.

$\mathrm{G}$ subunit: molecular weight of $13 \mathrm{kDa}$. This subunit shows considerable homology with the F-ATPase b subunit, which is a part of the F0 domain and functions as a hook that prevents the rotation of catalytic subunits. It has been suggested that the $\mathrm{G}$ subunit may have a similar function in V-ATPases by acting as part of the hook during the catalytic reaction.

\subsubsection{Turbine}

C subunit: molecular weight of $16 \mathrm{kDa}$. The $\mathrm{C}$ subunit is believed to be the main subunit with respect to the transport of protons across the membrane; the other biological functions which it has been attributed are described below.

c' and c' subunits: molecular weights of 17 and $19 \mathrm{kDa}$, respectively. Each of these subunits appears to be essential for the activity of the enzyme.

A subunit: molecular weight of $95 \mathrm{kDa}$. A copy of this subunit is necessary for enzyme activity and/or the shell of the enzyme.

D subunit: molecular weight of $40 \mathrm{kDa}$. This unit is peripherally associated with the V0 membrane sector on the cytosolic face of the membrane, but it contains a second, non-apparent transmembrane segment.

\subsubsection{Other subunits}

F subunit: molecular weight of $14 \mathrm{kDa}$. ATPase activity (ATP hydrolysis and proton transport) can be inhibited by antibodies specific to this subunit.

$\mathrm{H}$ subunit: molecular weight of $54 \mathrm{kDa}$. This subunit is probably involved in the regulation of enzyme activity and in communication between V-ATPase and proteins linked to other cell processes.

Another V-ATPase subunit classification system, proposed by Nishi and Forgac (2002), divides the subunits according to the domain to which they belong (Figure 2).

Interactions between the different subunits are essential for the correct functioning of V-ATPases (Xu et al., 1999). Jones et al. (2005), reported that the $\mathrm{C}$ and $\mathrm{G}$ subunits (Vma5p and Vma10p, respectively) are capable of strongly interacting with the E subunit (Vma4p). The N-terminus of the E subunit appears to be key not only in the regulation of the rotary molecular structure of V-ATPase but also in 
interactions with possible regulatory subunits (Jones et al., 2005). According to Jefferies and Forgac, 2008, interaction between the $\mathrm{H}$ subunit of the free $\mathrm{V} 1$ domain and the $\mathrm{F}$ subunit (subunit of rotary part), inhibits the ATP catalytic ability of V-ATPase.

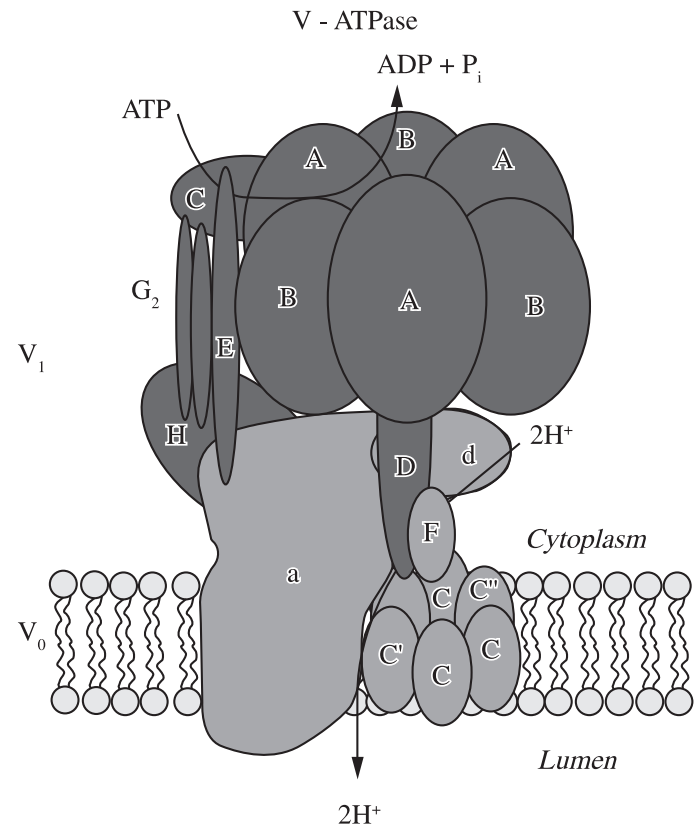

Figure 2. Diagram of V-ATPase. The cytosolic domain (in dark gray) is formed by three A subunits, three B subunits, three $\mathrm{G}$ subunits, and one $\mathrm{C}, \mathrm{D}, \mathrm{E}, \mathrm{F}$, and $\mathrm{H}$ subunit. The V0 transmembrane domain is formed by five subunits: a, c, c', c" and d. The V1 domain contains the catalytic unit (Nishi and Forgac, 2002).

\subsection{V-ATPase regulation}

Three major regulatory mechanisms have been described for V-ATPase: 1) the regulation of pump density, which allows different cells to maintain their cytoplasmic and vacuolar $\mathrm{pH}$ stable; 2) the regulation of V1 and V0 domain association/dissociation, for example, a decrease in glucose levels can cause a $70 \%$ dissociation of the V1 domains of the membrane; and 3 ) the regulation of secretory activity, via the maintenance of balance in the formation of bisulfite and binding efficiency between $\mathrm{H}+$ and the pump. Other mechanisms include the necessary modifications in the membrane potential for the generation of electrogenic force (Forgac, 1998; Peng et al., 1993) and alterations in the vacuolar transporter chaperone (Vtc) complex, which affect the conformation of the V0 domain and its function in vacuole fusion of the membrane) (Muller et al., 2003).

Table 3 shows the structure, function, and regulation of the different V-ATPase subunits (Torigoe et al., 2002).

\subsection{The C subunit}

The $\mathrm{C}$ subunit is a $40-\mathrm{kDa}$ protein located in the V1 domain of $\mathrm{V}$-ATPase. This protein is encoded by the ATP6V1C gene, also known as VATC, Vma5, ATP6C, ATP6D, and FLJ20057, EC 3.6.3.14; it is located at position 22 on the long arm of chromosome 8 (8q22.3) (Sun-Wada et al., 2003b; Inoue and Forgac, 2005; Drory et al., 2004; Pietrement et al., 2006). It encodes a vacuolar component of ATPase (V-ATPase) (Curtis and Kane 2002), an enzyme multisubunit that mediates the acidification of eukaryotic intracellular organelles (27) ATP6V1C1 and ATP6V1C2 a and $b$, two alternative transcript variants encoding different isoforms, have been identified in this gene.

Table 3. Structure, function and regulation of human V-ATPase (Torigoe et al., 2002).

\begin{tabular}{|c|c|c|c|c|c|c|c|}
\hline Domain & Subunit & $\begin{array}{c}\text { Encoding } \\
\text { gene }\end{array}$ & Chromosome & $\begin{array}{c}\text { Molecular } \\
\text { weight }(\mathbf{k D a})\end{array}$ & $\begin{array}{l}\text { Yeast } \\
\text { gene }\end{array}$ & Function & $\begin{array}{c}\text { Interacting } \\
\text { protein }\end{array}$ \\
\hline \multirow[t]{8}{*}{$\mathrm{V}_{1}$} & A & $\begin{array}{l}\text { ATP6A }_{1} \\
\text { ATP6A }_{2}\end{array}$ & $3 p 13-q 13.2$ & $70-73$ & VWA1 & $\begin{array}{l}\text { ATP hydrolysis NEM/ } \\
\text { NBD-CI binding site }\end{array}$ & \\
\hline & $\mathrm{B}$ & $\begin{array}{l}\text { ATP6B }_{1} \\
\text { ATP6B }_{2}\end{array}$ & $\begin{array}{l}\text { 2cen-q13 } \\
8 \text { p22-p21 }\end{array}$ & $56-58$ & VMA2 & ATP binding & \\
\hline & $\mathrm{C}$ & ATP6C & $8 \mathrm{p} 22-\mathrm{q} 21.3$ & $40-42$ & VMA5 & activity, $\mathrm{V}_{1}-\mathrm{V}_{0}$ assembly & \\
\hline & $\mathrm{D}$ & ATP6M & 14 & 34 & VMA8 & activity, assembly & \\
\hline & $\mathrm{E}$ & ATP6E & $22 \mathrm{q} 11.1$ & $31-33$ & VMA4 & activity, assembly & mSos, aldolase \\
\hline & $\mathrm{F}$ & ATP6S14 & 12 & 14 & VMA7 & activity, $\mathrm{V}_{1}-\mathrm{V}_{0}$ assembly & \\
\hline & G & ATP6G & $6 \mathrm{p} 21$ & $13-15$ & VMA10 & activity, assembly & \\
\hline & $\mathrm{H}$ & & & $50-54$ & VMA13 & activity & HIV-1 Nef \\
\hline \multirow[t]{5}{*}{$\mathrm{V}_{0}$} & a & ATP6N & $17 q 21$ & $100-116$ & $\begin{array}{l}\text { VPH1/ } \\
\text { STV1 }\end{array}$ & $\begin{array}{c}\text { proton translocation } \\
\text { bafilomycin-biding site }\end{array}$ & \\
\hline & $\mathrm{c}$ & ATP6L & $16 \mathrm{p} 13.3$ & 17 & VMA3 & $\begin{array}{l}\text { proton translocation } \\
\text { bafilomycin/DCCD- } \\
\text { bidingsite }\end{array}$ & $\begin{array}{c}\text { E5 } \\
\text { oncoprotein } \\
\beta_{1} \text { integrin }\end{array}$ \\
\hline & $c^{\prime}$ & & & 17 & VMA11 & proton translocation & \\
\hline & $c "$ & ATP6F & $1 \mathrm{p} 32.3$ & 19 & VMA16 & proton translocation & \\
\hline & $\mathrm{d}$ & ATP6N2 & & 38 & VMA6 & activity, assembly & \\
\hline
\end{tabular}


According to Smith et al. (2002), ATP6V1C2 $a$ and the $\mathrm{b}$ are present in the lungs, kidney, and epididymis, where they perform an actin-binding function.

Novel imaging techniques such as small-angle $\mathrm{x}$-ray scattering (SAXS) can provide information on pore shape and size distribution, electron density, and surface fractal dimension. SAXS, for example, has been used to describe the structure and morphology of the $\mathrm{C}$ subunit and its role in V-ATPase regulation (Svergun et al., 1998; Armbruster et al., 2004) (Figure 3).

Immunoelectron microscopy, which serves to determine the location and spatial distribution of different subunits, has been used to study the $\mathrm{C} 1$ subunit (Zhang et al., 2006; Chaban et al., 2005) (Figure 4). The model proposed by Zhang et al. (2006) coincided with that described by Drory et al. (2004), which established that the crystalline structure of the $\mathrm{C}$ subunit is formed by two globular domains linked by a flexible connection (Drory et al., 2004) (Figure 5).

For many authors, the key function of the $\mathrm{C}$ subunit is the regulation of reversible dissociation. According to Grüber (2005) and Armbruster et al. (2005), this subunit is intimately involved in the reversible dissociation of the V1 and V0 domains. The dissociation is possible due to the occupation of the subunit by nucleotides and conformational changes in the structure of the subunit (Gruber, 2005; Armbruster et al., 2005). In addition to establishing the crystalline structure of the $\mathrm{C}$ subunit and its importance in reversible dissociation as a control mechanism of V-ATPase activity, Forgac (2007) described

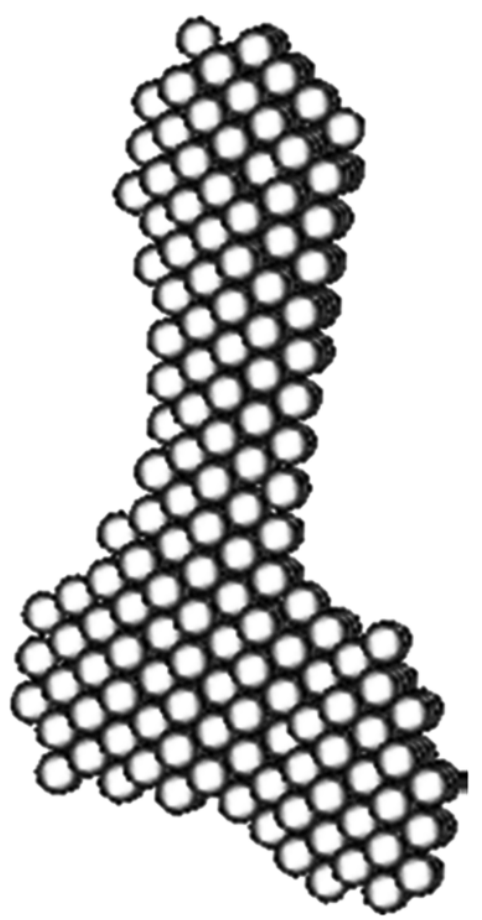

Figure 3. Low-resolution structure of the V-ATPase C subunit by small-angle X-ray scattering (Gruber, 2005). the relationship between the $\mathrm{C}$ subunit and the $\mathrm{E}$ and $\mathrm{G}$ subunits of the V1 domain and the a subunit of the V0 domain, and concluded that the $\mathrm{C}$ subunit was the primary mechanism responsible for enzyme control (Forgac, 2007; Inoue and Forgac, 2005).

In an experimental model, Peng et al. (1993) demonstrated that the $\mathrm{C}$ subunit was essential for the proton secretion function of V-ATPase as ATP hydrolysis was blocked in the absence of this unit. Using photoaffinity and fluorescence correlation spectroscopy, Armbrüster et al., 2005 demonstrated that the $\mathrm{C}$ subunit had more affinity for analogues of ADP than for analogues of ATP.

In the early 1990s, Puopolo et al. (1992) stated that the $\mathrm{C}$ subunit accelerated but was not essential for the V1V0 complex formation process, but their results were questioned in other studies from the same period that argued that the $\mathrm{C}$ subunit was the only regulator of the dissociative mechanism. This theory was supported by Drory et al. (2004), who reported that the $\mathrm{C}$ subunit was the only mechanism responsible for V-ATPase dissociation in vivo.

According to Voss et al. (2007), the C subunit is responsible for V-ATPase dissociation into cytosolic V1 and membranous $\mathrm{V} 0$ complexes via interaction with protein kinase A. The $\mathrm{C}$ subunit appears to be phosphorylated as part of the V1 complex but not as part of the V1V0 holoenzyme. Furthermore, both the phosphorylated and non-phosphorylated forms are capable of reassociating with the V1 complex from which they have been previously removed. These data suggest that the $\mathrm{C}$ subunit serves as a substrate for protein kinase A and that its phosphorylation

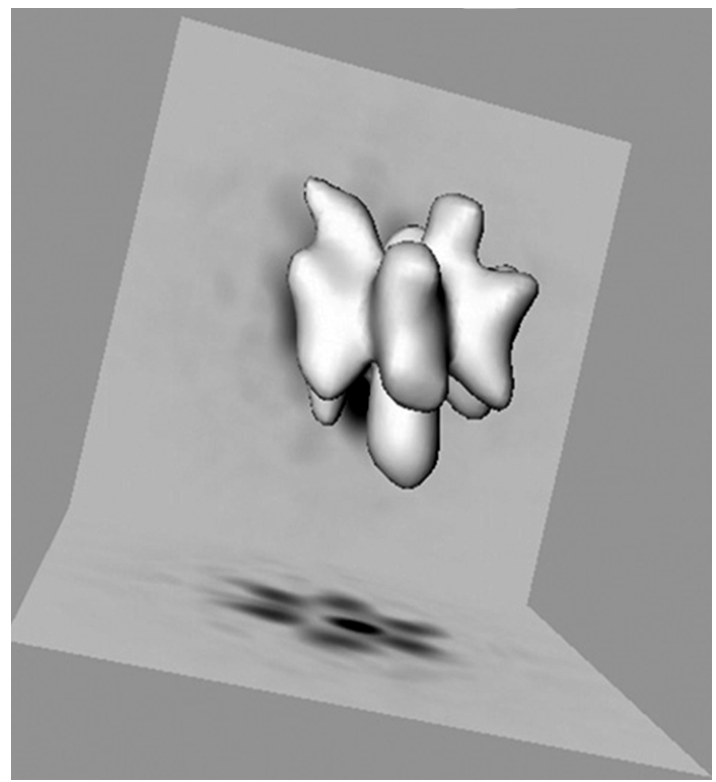

Figure 4. Structure of V1-ATPase without a C subunit shown by three-dimensional single-particle electron microscopy. Note the conformational change in the central mass of the V-ATPase (Gruber, 2005). 
may be the main mechanism underlying the formation of the active V1V0 holoenzyme (Voss et al., 2007).

Another reversible dissociation mechanism regulated by the $\mathrm{C}$ subunit underlies the separation of the holoenzyme V1V0 into V1 and V0 subcomplexes, which occurs through the binding of the $\mathrm{C}$ subunit and $\mathrm{F}$-actin proximal to the basement membrane of epithelial cells. The $\mathrm{C}$ subunit appears to act as an anchor protein that allows V-ATPase to bind to the actin cytoskeleton (Vitavska et al., 2003).

According to Otero-Rey et al. (2008), the V-ATPase $\mathrm{C} 1$ subunit appears to be responsible for the assembly of the V0 membrane component and the cytosolic catalytic component (Figure 6). The RAVE complex (a regulator of V-ATPases and endosomal membranes) needs to be present for optimal C subunit and V-ATPase assembly to occur (Forgac, 2007; Smardon and Kane, 2007).

In an in vitro study, Smardon and Kane (2007), found that while V1V0 assembly took place in the absence of the $\mathrm{C}$ subunit, the resulting complex was highly unstable and that V-ATPase activity was extremely low; this would suggest that the $\mathrm{C}$ subunit is exclusively responsible for regulating the assembly of the V1V0 complex. Similarly, in the absence of RAVE, the $\mathrm{C}$ subunit has been found to be incapable of assembling into V-ATPase, resulting in the loss of enzyme activity (Smardon and Kane, 2007). These data are supported by findings by Keenan et al. (2002), which showed a reduction of over $48 \%$ in catalytic activity that
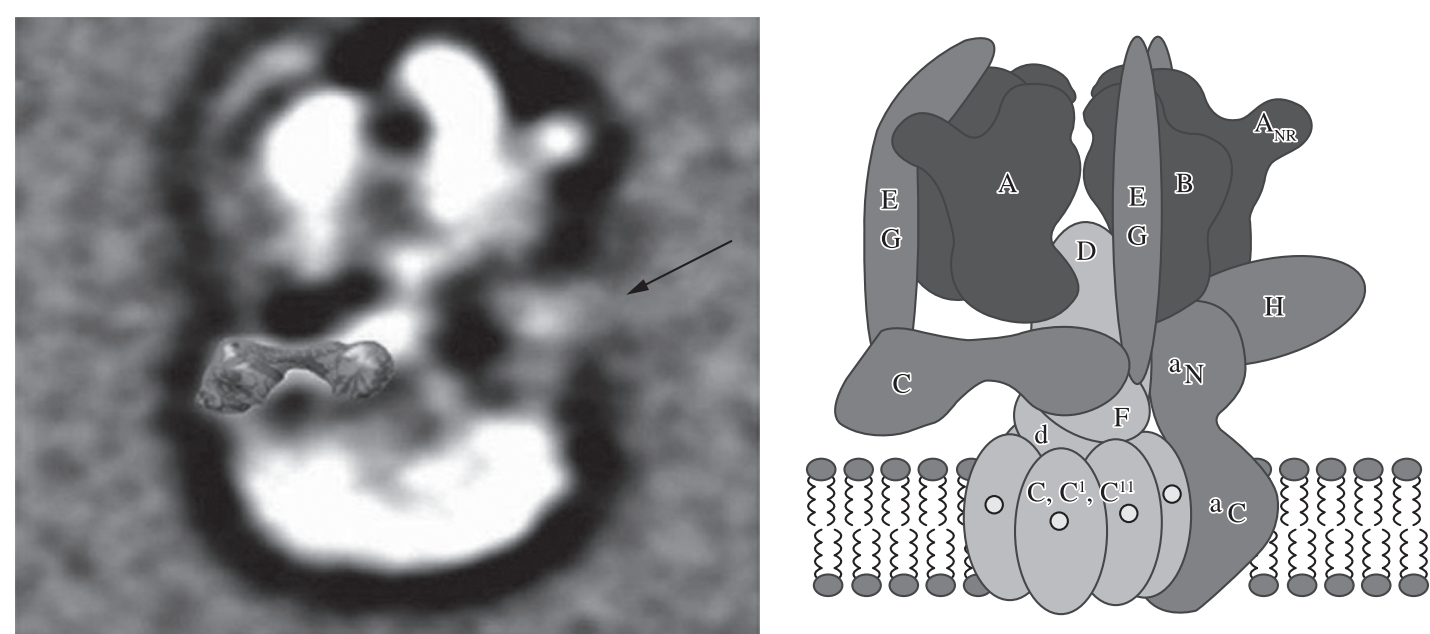

Figure 5. Image of crystal structure of the C subunit and schematic working model (Zhang et al., 2006).
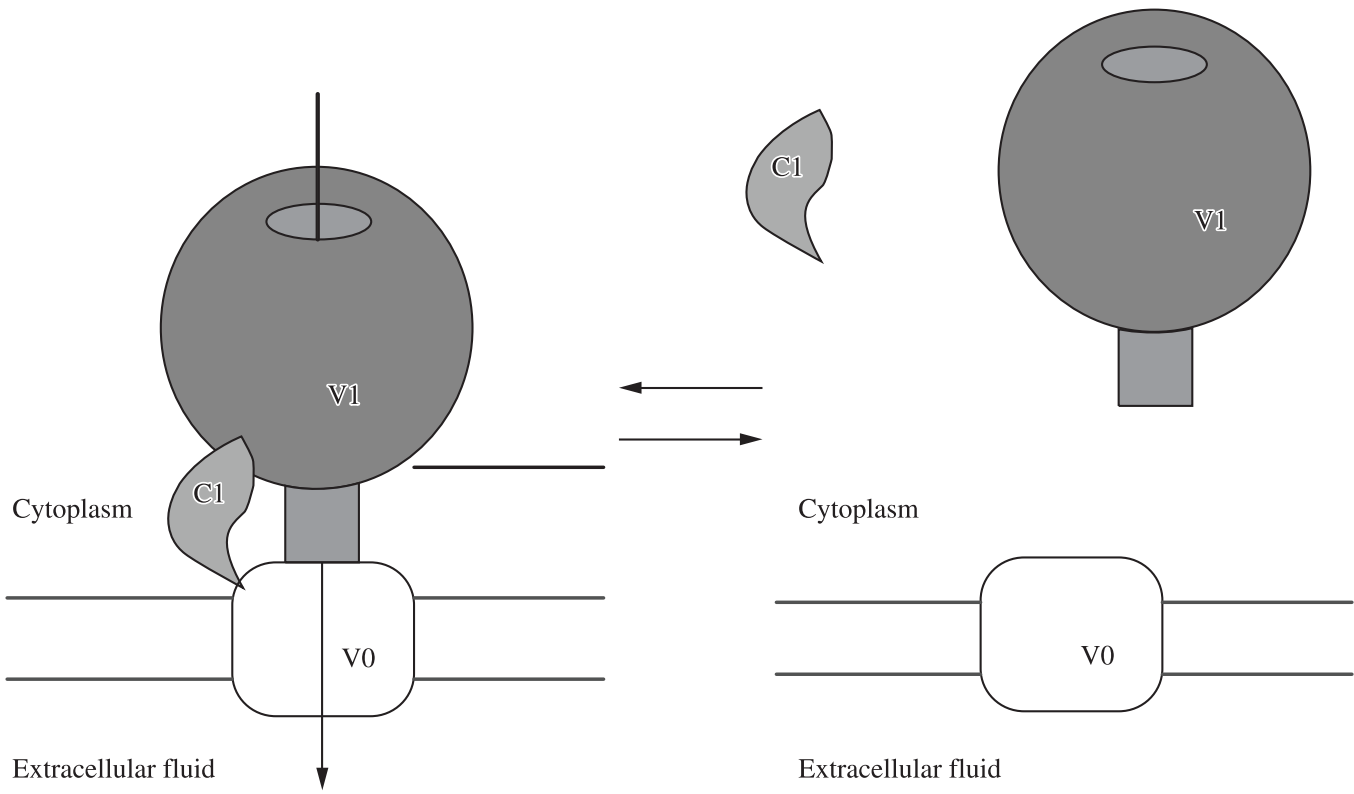

Extracellular fluid

Figure 6. The dissociation of ATPase into V1 and V0 is regulated by the C1 subunit (Otero-Rey et al., 2008). 
did not affect enzyme assembly in experimental models with different mutations in the $\mathrm{C}$ subunit.

\section{Conclusions and Perspectives}

In conclusion, we note that the V-ATPases are involved in a larger number of biological functions as classically thought. The molecular structure of the protein and the location of the $\mathrm{C}$ subunit in the enzyme complex, clearly explains the implication of it in controlling the dissociation of V1 and V0 domain, a fact which is further supported by numerous studies. For this reason we consider extremely important further research on this subunit, in order to establish its relationship with pathological phenomena such as cancer, metastasis, etc. Our research group has found that ATP6V1C1 levels were significantly higher in patients with OSCC than in healthy controls, with expression increasing with higher tumor stage. This phenomenon can be used as a therapeutic target through the use of specific inhibitors of V-ATPases in the control of $\mathrm{pH}$. The future of these molecules in cancer treatment involves measuring the overexpression of specific V-ATPase subunits in tumors to be treated and then using inhibitors specific for the subunits being expressed in a synergistic approach. This will allow clinicians to provide more specific treatment, while also minimising adverse effects (Perez-Sayans et al., 2009a,b, 2010).

\section{References}

ARMBRUSTER, A., HOHN, C., HERMESDORF, A., SCHUMACHER, K., BORSCH, M. and GRUBER, G., 2005. Evidence for major structural changes in subunit $\mathrm{C}$ of the vacuolar ATPase due to nucleotide binding. FEBS Letters, vol. 579, no. 9, p. 1961-1967. PMid:15792803. http://dx.doi.org/10.1016/j. febslet.2005.02.042

ARMBRUSTER, A., SVERGUN, DI., COSKUN, U., JULIANO, S., BAILER, SM. and GRUBER, G., 2004. Structural analysis of the stalk subunit Vma5p of the yeast V-ATPase in solution. FEBS Letters, vol. 570, no. 1-3, p. 119-125. PMid:15251451. http://dx.doi.org/10.1016/j.febslet.2004.06.029

BAARS, TL., PETRI, S., PETERS, C. and MAYER, A., 2007. Role of the V-ATPase in regulation of the vacuolar fission fusion equilibrium. Molecular Biology of the Cell, vol. 18, no. 10, p. 3873-3882. PMid:17652457. PMCid:1995711. http://dx.doi. org/10.1091/mbc.E07-03-0205

BOYER, PD., 1993. The binding change mechanism for ATP synthase--some probabilities and possibilities. Biochimica et Biophysica Acta, vol. 1140, no. 3, p. 215-250. http://dx.doi. org/10.1016/0005-2728(93)90063-L

BRETON, S. and BROWN, D., 2007. New insights into the regulation of V-ATPase-dependent proton secretion. American Journal of Physiology - Renal Physiology, vol. 292, no. 1, p. F1-10. PMid:17032935. http://dx.doi.org/10.1152/ajprenal.00340.2006

CHABAN, YL., JULIANO, S., BOEKEMA, EJ. and GRUBER, G., 2005. Interaction between subunit C (Vma5p) of the yeast vacuolar ATPase and the stalk of the C-depleted V(1) ATPase from Manduca sexta midgut. Biochimica et Biophysica Acta, vol. 1708 , no. 2 , p. 196-200.
CIPRIANO, DJ., WANG, Y., BOND, S., HINTON, A., JEFFERIES, KC, QI, J. and FORGAC, M., 2008. Structure and regulation of the vacuolar ATPases. Biochimica et Biophysica Acta (BBA) Bioenergetics, vol. 1777, no. 7-8, p. 599-604.

CURTIS, KK. and KANE, PM., 2002. Novel Vacuolar H+ATPase Complexes Resulting from Overproduction of Vma5p and Vma13p. Journal of Biological Chemistry, vol. 277, no. 4, p. 2716-2724. PMid:11717306. http://dx.doi.org/10.1074/jbc. M107777200

DOMÍNGUEZ, L. and TUENA, M., 2005. ATP sintasa: un complejo proteico con gran versatilidad estructural y funcional. Tip Revista Especializada en Ciencias Químico-Biológicas, vol. 8, no. 1 , p. 18-27.

DRORY, O. and NELSON, N. 2006. The emerging structure of vacuolar ATPases. Physiology, vol. 21, p. 317-325. PMid:16990452. http://dx.doi.org/10.1152/physiol.00017.2006

DRORY, O., FROLOW, F. and NELSON, N., 2004. Crystal structure of yeast V-ATPase subunit $\mathrm{C}$ reveals its stator function. EMBO reports, vol. 5, no. 12, p. 1148-1152. PMid:15540116. PMCid:1299189. http://dx.doi.org/10.1038/sj.embor.7400294

FINBOW, ME. and HARRISON, MA., 1997. The vacuolar H+ATPase: a universal proton pump of eukaryotes. Biochemical Journal, vol. 324, pt. 3, p. 697-712.

FORGAC, M., 1998. Structure, function and regulation of the vacuolar (H+)-ATPases. FEBS Letters, vol. 440, no. 3, p. 258-263. http://dx.doi.org/10.1016/S0014-5793(98)01425-2

FORGAC, M., 2007. Vacuolar ATPases: rotary proton pumps in physiology and pathophysiology. Nature Reviews Molecular Cell Biology, vol. 8, no. 11, p. 917-929. PMid:17912264. http:// dx.doi.org/10.1038/nrm2272

GRUBER, G., 2005. Structural features and nucleotide-binding capability of the $\mathrm{C}$ subunit are integral to the regulation of the eukaryotic V1Vo ATPases. Biochemical Society Transactions, vol. 33, pt. 4, p. 883-885. PMid:16042619.

HARVEY, WR. and WIECZOREK, H., 1997. Animal plasma membrane energization by chemiosmotic H+ V-ATPases. Journal of Experimental Biology, vol. 200, pt. 2, p. 203-216. PMid:9050228.

HARVEY, WR., 1992. Physiology of V-ATPases. Journal of Experimental Biology, vol. 172, p. 1-17.

INOUE, T. and FORGAC, M., 2005. Cysteine-mediated Crosslinking Indicates That Subunit C of the V-ATPase Is in Close Proximity to Subunits E and G of the V1 Domain and Subunit a of the V0 Domain. Journal of Biological Chemistry, vol. 280, no. 30, p. 27896-27903. PMid:15951435. http://dx.doi.org/10.1074/ jbc.M504890200

INOUE, T., WANG, Y., JEFFERIES, K., QI, J., HINTON, A. and FORGAC, M., 2005. Structure and regulation of the V-ATPases. Journal of Bioenergetics and Biomembranes, vol. 37, no. 6, p. 393-398. PMid:16691471. http://dx.doi.org/10.1007/ s10863-005-9478-8

JEFFERIES, KC. and FORGAC, M., 2008. Subunit H of the Vacuolar (H+) ATPase Inhibits ATP Hydrolysis by the Free V1 Domain by Interaction with the Rotary Subunit F. Journal of Biological Chemistry, no. 8, p. 4512-4519. PMid:18156183. PMCid:2408380.

JONES, RP., DUROSE, LJ., FINDLAY, JB. and HARRISON, MA., 2005. Defined sites of interaction between subunits E (Vma4p), 
$\mathrm{C}$ (Vma5p), and G (Vma10p) within the stator structure of the vacuolar H+-ATPase. Biochemistry, vol. 44, no. 10, p. 3933-3941.

KANE, PM., 1999. Introduction: V-ATPases 1992-1998. Journal of Bioenergetics and Biomembranes, vol. 31, no. 1, p. 3-5. PMid:10340843. http://dx.doi.org/10.1023/A:1001884227654

KAWASAKI-NISHI, S., NISHI, T. and FORGAC, M., 2003. Proton translocation driven by ATP hydrolysis in V-ATPases. FEBS Letters, vol. 545, no. 1, p. 76-85. http://dx.doi.org/10.1016/ S0014-5793(03)00396-X

KEENAN, CK. and KANE, PM., 2002. Novel Vacuolar H+ATPase Complexes Resulting from Overproduction of Vma5p and Vma13p J. Biol. Chem., 2002, 277, 4, 2716-2724

KURASHIMA, K., NUMATA, M., YACHIE, A., SAI, Y., ISHIZAKA, N., FUJIMURA, M., MATSUDA, T. and OHKUMA, S.1996. The role of vacuolar $\mathrm{H}(+)$-ATPase in the control of intragranular $\mathrm{pH}$ and exocytosis in eosinophils. Laboratory Investigation, vol. 75, no. 5, p. 689-698. PMid:8941214.

MARSHANSKY, V. and FUTAI, M., 2008. The V-type H+-ATPase in vesicular trafficking: targeting, regulation and function. Current Opinion in Cell Biology, vol. 20, no. 4, p. 415-26.

MARTÍNEZ-MUNOZ, GA. and KANE, P., 2008. Vacuolar and plasma membrane proton pumps collaborate to achieve cytosolic $\mathrm{pH}$ homeostasis in yeast. Journal of Biological Chemistry, vol. 283, no. 29, p. 20309-20319. PMid:18502746. PMCid:2459297. http://dx.doi.org/10.1074/jbc.M710470200

MARTÍNEZ-ZAGUILAN, R., LYNCH, RM., MARTINEZ, GM. and GILLIES, RJ., 1993. Vacuolar-type H(+)-ATPases are functionally expressed in plasma membranes of human tumor cells. American Journal of Physiology - Cell Physiology, vol. 265, no. 4, p. C1015-1029.

MIURA, GI., FROELICK, GJ., MARSH, DJ., STARK, KL. and PALMITER, RD., 2003. The $d$ Subunit of the Vacuolar ATPase (Atp6d) is Essential for Embryonic Development. Transgenic research, vol. 12 , no. 1 .

MORIYAMA, Y. and NELSON, N., 1989. H+-translocating ATPase in Golgi apparatus. Characterization as vacuolar $\mathrm{H}+$-ATPase and its subunit structures. Journal of Biological Chemistry, vol. 264, no. 31 , p. $18445-18450$.

MULLER, O., NEUMANN, H., BAYER, MJ. and MAYER, A., 2003. Role of the Vtc proteins in V-ATPase stability and membrane trafficking. Journal of Cell Science, vol. 116, no. 6, p. 1107-1115. PMid:12584253. http://dx.doi.org/10.1242/jcs.00328

NANDA, A., BRUMELL, JH., NORDSTROM, T., KJELDSEN, L., SENGELOV, H., BORREGAARD, N., ROTSTEIN, OD. and GRINSTEIN, S., 1996. Activation of Proton Pumping in Human Neutrophils Occurs by Exocytosis of Vesicles Bearing Vacuolar-type H+-ATPases. Journal of Biological Chemistry, vol. 271, no. 27, p. 15963-15970. PMid:8663143. http://dx.doi. org/10.1074/jbc.271.27.15963

NELSON, H. and NELSON, N., 1989. The progenitor of ATP synthases was closely related to the current vacuolar H+-ATPase. FEBS Letters, vol. 247, no. 1, p. 147-153. http:// dx.doi.org/10.1016/0014-5793(89)81259-1

NELSON, N. and HARVEY, WR., 1999. Vacuolar and Plasma Membrane Proton-Adenosinetriphosphatases. Physiological Reviews, vol. 79, no. 2, p. 361-385. PMid:10221984.
NELSON, N., 1992. Evolution of organellar proton-ATPases. Biochimica et Biophysica Acta, vol. 1100, no. 2, p. 109-124. http://dx.doi.org/10.1016/0005-2728(92)90072-A

NELSON, N., PERZOV, N., COHEN, A., HAGAI, K., PADLER, V. and NELSON, H., 2000. The cellular biology of proton-motive force generation by V-ATPases. Journal of Experimental Biology, vol. 203, pt. 1, p. 89-95

NISHI, T. and FORGAC, M., 2002. The vacuolar (H+)-ATPases-nature's most versatile proton pumps. Nature Reviews Molecular Cell Biology, vol. 3, no. 2, p. 94-103. PMid:11836511. http:// dx.doi.org/10.1038/nrm729

OTERO-REY, EM., SOMOZA-MARTIN, M., BARROSANGUEIRA, F. and GARCIA-GARCIA, A., 2008. Intracellular $\mathrm{pH}$ regulation in oral squamous cell carcinoma is mediated by increased V-ATPase activity via over-expression of the ATP6V1C1 gene. Oral Oncology, vol. 44, no.2, p. 193-199. PMid:17467328. http://dx.doi.org/10.1016/j.oraloncology.2007.02.011

PENG, S., STONE, D. and XIE, X., 1993. Reconstitution of recombinant $40-\mathrm{kDa}$ subunit of the clathrin-coated vesicle $\mathrm{H}(+)$ ATPase. Journal of Biological Chemistry, vol. 268, no. 31, p. 23519-23523. PMid:8226880.

PEREZ-SAYANS, M., GARCIA-GARCIA, A., REBOIRAS-LOPEZ, MD. and GANDARA-VILA, P., 2009a. Role of V-ATPases in solid tumors: Importance of the subunit $\mathrm{C}$ (Review). International Journal of Oncology, vol. 34, no. 6, p. 1513-1520. http://dx.doi. org/10.3892/ijo_00000280

PÉREZ-SAYÁNS, M., REBOIRAS-LÓPEZ, MD., SOMOZAMARTÍN, JM., BARROS-ANGUEIRA, F., GAYOSO-DIZ, P., GÁNDARA-REY, JM. and GARCÍA-GARCÍA, A., 2010. Measurement of ATP6V1C1 expression in brush cytology samples as a diagnostic and prognostic marker in oral squamous cell carcinoma. Cancer Biology \& Therapy, vol. 9, no. 12, p. 1-8.

PEREZ-SAYANS, M., SOMOZA-MARTIN, JM., BARROSANGUEIRA, F., REY, JM. and GARCIA-GARCIA, A., 2009b. V-ATPase inhibitors and implication in cancer treatment. Cancer Treatment Reviews, vol. 35, no. 8, p. 707-13. PMid:19758758. http://dx.doi.org/10.1016/j.ctrv.2009.08.003

PHILIPPE, JM., DUBOIS, JM., ROUZAIRE-DUBOIS, B., CARTRON, PF., VALLETTE, F. and MOREL, N., 2002. Functional expression of V-ATPases in the plasma membrane of glial cells. Glia, vol. 37, no. 4, p. 365-373 . PMid:11870875. http://dx.doi.org/10.1002/glia.10041

PIETREMENT, C., SUN-WADA, GH., SILVA, ND., MCKEE, M., MARSHANSKY, V. and BROWN, D., FUTAI M. and BRETON, S., 2006. Distinct expression patterns of different subunit isoforms of the V-ATPase in the rat epididymis. Biology of Reproduction, vol. 74, no. 1, p. 185-194. PMid:16192400. http://dx.doi.org/10.1095/biolreprod.105.043752

PUOPOLO, K., SCZEKAN, M., MAGNER, R. and FORGAC, M., 1992. The 40-kDa subunit enhances but is not required for activity of the coated vesicle proton pump. Journal of Biological Chemistry, vol. 267, no. 8, p. 5171-5176. PMid:1531980.

QI, J. and WANG, Y., FORGAC, M., 2007. The vacuolar (H+)ATPase: subunit arrangement and in vivo regulation. Journal of Bioenergetics and Biomembranes, vol. 39, no. 5-6, p. 423-426. PMid:18040762. http://dx.doi.org/10.1007/s10863-007-9116-8

SAROUSSI, S. and NELSON, N. 2008. Vacuolar H(+)-ATPase-an enzyme for all seasons. Pflugers Archiv, vol. 457, no. 3, p. 581-587. PMid:18853182. http://dx.doi.org/10.1007/s00424-008-0458-9 
SCHOONDERWOERT, VTG., HOLTHUIS, JCM., TANAKA, S., TOOZE, SA. and MARTENS, GJM., 2000. Inhibition of the vacuolar H+-ATPase perturbs the transport, sorting, processing and release of regulated secretory proteins. European Journal of Biochemistry, vol. 267, no. 17, p. 5646-5654.

SMARDON, AM. and KANE, PM., 2007. RAVE is essential for the efficient assembly of the $\mathrm{C}$ subunit with the vacuolar $\mathrm{H}(+)$-ATPase. Journal of Biological Chemistry, vol. 282, no. 36, p. 26185-26194. PMid:17623654. http://dx.doi.org/10.1074/ jbc.M703627200

SMITH, AN., BORTHWICK, KJ. and KARET, FE., 2002. Molecular cloning and characterization of novel tissue-specific isoforms of the human vacuolar $\mathrm{H}(+)$-ATPase $\mathrm{C}, \mathrm{G}$ and d subunits, and their evaluation in autosomal recessive distal renal tubular acidosis. Gene, vol. 297, no. 1-2, p. 169-177. http://dx.doi.org/10.1016/ S0378-1119(02)00884-3

SMITH, AN., JOURET, F., BORD, S., BORTHWICK, KJ., ALLAMKI, RS., WAGNER, CA., IRELAND, DC., CORMIER-DAIRE, V., FRATTINI, A., VILLA, A., KORNAK, U., DEVUYST, O. and KARET, FE., 2005. Vacuolar H+-ATPase d2 subunit: molecular characterization, developmental regulation, and localization to specialized proton pumps in kidney and bone. Journal of the American Society of Nephrology, vol. 16, no. 5, p. 1245-1256. PMid:15800125. http://dx.doi.org/10.1681/ASN.2004090761

SMITH, AN., LOVERING, RC., FUTAI, M., TAKEDA, J., BROWN, D. and KARET, FE., 2003. Revised Nomenclature for Mammlian Vacuolar-Type H+-ATPase Subunit Genes. Molecular Cell, vol. 12, p. 801-803. http://dx.doi.org/10.1016/ S1097-2765(03)00397-6

STEVENS, TH. and FORGAC, M., 1997. Structure, function and regulation of the vacuolar (H+)-ATPase. Annual Review of Cell and Developmental Biology, vol. 13, p. 779-808. PMid:9442887. http://dx.doi.org/10.1146/annurev.cellbio.13.1.779

SUN-WADA, G., WADA, Y. and FUTAI, M., 2004. Diverse and essential roles of mammalian vacuolar-type proton pump ATPase: toward the physiological understanding of inside acidic compartments. Biochimica et Biophysica Acta (BBA) Bioenergetics, vol. 1658, no. 1-2, p. 106-114.

SUN-WADA, GH., WADA, Y. and FUTAI, M., 2003a. Vacuolar $\mathrm{H}+$ pumping ATPases in luminal acidic organelles and extracellular compartments: common rotational mechanism and diverse physiological roles. Journal of Bioenergetics and Biomembranes, vol. 35, no. 4, p. 347-358. PMid: 14635780. http://dx.doi.org/10.1023/A:1025780932403

SUN-WADA, GH., YOSHIMIZU, T., IMAI-SENGA, Y., WADA, Y. and FUTAI, M., 2003b. Diversity of mouse protontranslocating ATPase: presence of multiple isoforms of the C, $\mathrm{d}$ and G subunits. Gene, vol. 302, no. 1-2, p. 147-153. http://dx.doi. org/10.1016/S0378-1119(02)01099-5

SVERGUN, DI., KONRAD, S., HUSS, M., KOCH, MH., WIECZOREK, H., ALTENDORF, K., VOLKOV, VV. and
GRÜBER, G., 1998. Quaternary structure of V1 and F1 ATPase: significance of structural homologies and diversities. Biochemistry, vol. 37 , no. 51, p. 17659-17663.

TORIGOE, T., IZUMI, H., ISE, T., MURAKAMI, T., URAMOTO, H., ISHIGUCHI, H., YOSHIDA, Y., TANABE, M., NOMOTO, M. and KOHNO, K., 2002. Vacuolar H(+)-ATPase: functional mechanisms and potential as a target for cancer chemotherapy. Anticancer Drugs, vol. 13, no. 3, p. 237-243. PMid:11984067. http://dx.doi.org/10.1097/00001813-200203000-00005

Van HILLE, B., VANEK, M., RICHENER, H., GREEN, JR. and BILBE, G., 1993. Cloning and tissue distribution of subunits C, $\mathrm{D}$, and $\mathrm{E}$ of the human vacuolar $\mathrm{H}(+)$-ATPase. Biochemical and Biophysical Research Communications, vol. 30;197, no. 1, p. 15-21.

VITAVSKA, O., WIECZOREK, H. and MERZENDORFER, H., 2003. A Novel Role for Subunit $C$ in Mediating Binding of the $\mathrm{H}+\mathrm{V}$-ATPase to the Actin Cytoskeleton. Journal of Biological Chemistry, vol. 278, no. 20, p. 18499-18505. PMid:12606563. http://dx.doi.org/10.1074/jbc.M212844200

VOSS, M., VITAVSKA, O., WALZ, B., WIECZOREK, H. and BAUMANN, O., 2007. Stimulus-induced phosphorylation of vacuolar $\mathrm{H}(+)$-ATPase by protein kinase A. Journal of Biological Chemistry, vol. 282, no. 46, p. 33735-33742. PMid:17872947. http://dx.doi.org/10.1074/jbc.M703368200

WADA, Y., SUN-WADA, GH., TABATA, H. and KAWAMURA, N., 2008. Vacuolar-type proton ATPase as regulator of membrane dynamics in multicellular organisms. Journal of Bioenergetics and Biomembranes, vol. 40, no. 1, p. 53-57. PMid:18214654. http://dx.doi.org/10.1007/s10863-008-9128-z

WIECZOREK, H, BROWN, D., GRINSTEIN, S., EHRENFELD, J. and HARVEY, WR., 1999. Animal plasma membrane energization by proton-motive V-ATPases. Bioessays, vol. 21, no. 8, p. 637-648. http://dx.doi.org/10.1002/(SICI)15211878(199908)21:8\%3C637::AID-BIES3\%3E3.0.CO;2-W

WILKENS, S., ZHANG, Z. and ZHENG, Y., 2005. A structural model of the vacuolar ATPase from transmission electron microscopy. Micron, vol. 36, no. 2, p. 109-126. PMid:15629643. http://dx.doi.org/10.1016/j.micron.2004.10.002

XU, T., VASILYEVA, E. and FORGAC, M., 1999. Subunit interactions in the clathrin-coated vesicle vacuolar $(\mathrm{H}(+))$-ATPase complex. Journal of Biological Chemistry, vol. 274, no. 41, p. 28909-28915. PMid:10506135. http://dx.doi.org/10.1074/ jbc.274.41.28909

ZHANG, J., MYERS, M. and FORGAC, M., 1992. Characterization of the V0 domain of the coated vesicle (H+)-ATPase. Journal of Biological Chemistry, vol. 267, no. 14, p. 9773-9778. PMid:1533640.

ZHANG, Z., INOUE, T., FORGAC, M. and WILKENS, S., 2006. Localization of subunit $\mathrm{C}(\mathrm{Vma} 5 \mathrm{p})$ in the yeast vacuolar ATPase by immuno electron microscopy. FEBS Letters, vol. 580, no. 8, p. 2006-2010. PMid:16546180. http://dx.doi.org/10.1016/j. febslet.2006.03.001 